\title{
Climate change and livelihood practices in Vanuatu
}

\author{
Desirée Hetzel and Arno Pascht
}

\begin{abstract}
As Vanuatu is classified as extremely vulnerable to adverse effects of climate change, adaptation measures are given high priority by the government, development organisations, and NGOs. Projects which combine food security and adaptation to climate change introduce new cultivation methods and techniques. They are intended to prepare people for adverse effects of climate change such as extreme weather events. Tropical Cyclone Pam in 2015 was declared as such an extreme weather event linked to climate change. This chapter investigates livelihood practices of people in two villages in Vanuatu (Siviri and Dixon Reef) during and after Pam and after inhabitants participated in an adaptation and food security project. People in these villages employ a wide range of livelihood practices in order to secure their living and try continuously to extend their possibilities. We argue that diversification, which is a fundamental principle found in Oceania in the context of cultivation, is additionally transferred in Vanuatu to other possibilities than to secure the cultivation of food crops, namely to obtain monetary income. Because this wider context is central for the people, as well as for research, we chose a perspective that focuses on practices of the people in Siviri and Dixon Reef.
\end{abstract}

Cite this article: Hetzel, D. \& Pascht, A. (2019): Climate change and livelihood practices in Vanuatu. In: Klöck, C. \& Fink, M. (eds.): Dealing with climate change on small islands: Towards effective and sustainable adaptation? (pp. 195-216). Göttingen: Göttingen University Press. https://doi.org/10.17875/gup2019-1217 


\section{$1 \quad$ Introduction}

In this chapter, we look at livelihood practices in two rural communities in Vanuatu and examine how daily practices are directly related to today's life of (environmental) changes. Interacting with these changes, people tend not to focus on one livelihood practice but follow the principle of diversification.

Since climate change is one of the prominent topics in political discourses in Vanuatu, various government and non-governmental organisations have implemented a bundle of measures in the form of projects for food security and climate change adaptation. Many of these measures concentrate on the practice of horticulture and want to provide farmers new tools for new challenges related to growing food in their gardens. Two of the longer-term projects ${ }^{1}$ were conducted in the two village communities of Siviri on the main island Efate and Dixon Reef on Malekula, an island in the northeast of the country (see Figure 1). In both villages, programmes focus on innovative techniques and methods for cultivation designed for sustainable and effective agriculture. For about five years inhabitants attended numerous workshops and training sessions. These involved learning practices and new knowledge about environmental changes and information on predictions of increasingly adverse weather events. During the projects' lifetime, in March 2015, after two and three years respectively, Vanuatu was hit by Tropical Cyclone Pam. This event was followed by an extended dry period, which was identified as an El Niño phase by politicians, the media, and our interlocutors. In political and media discourse it was additionally referred to as proof of progressing challenges resulting from climate change.

In this chapter we concentrate on the time after this event when people engaged in a range of different activities in order to secure their livelihoods. Even though programs intended them to focus on the practices of gardening and apply new techniques, we experienced that cultivation of food crops was one among many practices women and men in Siviri and Dixon Reef followed.

For the last few years, social science scholars working on climate change have asked for actor-centred approaches to research on climate change in Oceania. Whereas the media mainly focuses on concepts like vulnerability and (lacking) resilience, these scholars demand avoiding a narrative of victimisation by showing islanders' agency on different levels (Barnett \& Campbell, 2010; Farbotko, 2010; Lazrus, 2012; Crook \& Rudiak-Gould, 2018a). This implies looking at practices of Pacific Islanders in political contexts as well as in their daily lives. Important questions are, in our view, how people encounter so-called adaptation strategies and what they actually do in their daily lives, which may or may not have anything to do with these encounters. We suggest that this perspective is crucial to achieve a

\footnotetext{
${ }^{1}$ Projects have been realised by governmental and non-governmental organisations, funded by mostly international organisations. All of them are supervised by the National Advisory Board for Climate Change and Disaster Risk Reduction.
} 
better understanding of processes often subsumed under the concept of adaptation.

Whereas environmental discourses in political and media contexts often focus on impacts of climate change, irreversible future changes and challenges, and the question of resilience, we explore the wider context of recent livelihood practices of ni-Vanuatu during and after a period of events related to the phenomenon of climate change. We do this for two research sites: Siviri and Dixon Reef. Our research focuses on the period between 2016 and 2019 - after Tropical Cyclone Pam and during and after the El Niño event. By looking at livelihood practices we want to explore how people are making their living (see Ingold, 2002).

We use the expression of livelihood practices as an analytical tool for regular (but possibly not permanent) activities which contribute to acquiring food and other necessities of life. In the following, we deal with single practices as well as with bundles of practices. 'Bundles of livelihood practices' refer to subordinate labels like cultivation, fishing, wage labour (of a certain kind), etc. By 'livelihood practices' we mean not only ways in which people secure their livelihoods but equally ways in which they relate to and interact with and within their environment in a wider sense (Ingold, 2002, p. 5). Accordingly, we focus on those activities people mentioned when they tried to explain their approach to obtaining the necessities of life - this means mainly monetary income, cultivated food, and exchanged goods. Furthermore, 'environment' is used here in a broad sense, including all aspects of human and other-than-human life (see Pascht \& Dürr, 2017) and its materialisation. Like people in Vanuatu and elsewhere in Melanesia we thus do not separate the 'natural' or 'physical' sphere from others, e.g. the social (Hviding, 2003).

This contribution engages with the following questions: What did people tell us are their most important activities in order to secure their livelihoods? How do people create and maintain (configurations of) livelihood practices that are meaningful for them? (How) do they thereby refer to or involve practices designed as adaptation strategies for climate change and demonstrated by staff of government and non-governmental organisations?

We show that diversification is a fundamental principle of Siviri and Dixon Reef villagers, which not only has existed for some decades but also is linked with other important ideas and praxis of the people. This suggests that it may be too restricted to confine the perspective on diversification as an adaptation ${ }^{2}$ to environmental changes.

\footnotetext{
2 As we want to broaden the perspective and make views of the people central to our research, we do not use adaptation in our analysis as a theoretical concept.
} 


\section{Climate change discourses and practices in Oceania}

\subsection{Encountering climate change in Oceania}

Over the last two decades there have been numerous publications in the social sciences on climate change-related topics in Oceania. Many recent ones focus on either how people at the community level are involved in practices around climate change and their perspectives on ongoing climatic changes and discourses (for Vanuatu see, e.g., Warrick, 2009, 2011; McNamara \& Prasad 2013; see also Flores Palacios, this volume; Moncada \& Bambrick, this volume) or how people in Oceania deal with global climate change politics and knowledge in the region and in individual countries (Lazrus, 2012; Rudiak-Gould, 2013; Hermann \& Kempf, 2014; Hetzel \& Pascht, 2017, 2018; Farbotko, 2010; Crook \& Rudiak-Gould, 2018b).

Studies in social science show that Pacific Islanders are active participants in global and national discourses (Rudiak-Gould, 2013; Lazrus, 2012). Furthermore, many focus on the community level in order to better understand how people on the ground perceive and deal with climate change-related implications (Granderson, 2014). Climate change topics are thus also part of the narratives that exist in the communities around Oceania, and the same applies to Vanuatu specifically, as we show in the next sections. It is furthermore important to look at how Pacific Islanders, and in our case people in Vanuatu, encounter ideas and practices related to climate change (Hetzel \& Pascht, 2017). Equally, local activities should be recognised and Pacific Islanders should be seen as actors on both local and global scales (Lazrus, 2012).

Anthropological research in particular is often concerned with people's local experiences and different perspectives on the concept of climate change and on environmental changes and local responses (Rudiak-Gould, 2011; Crook \& Rudiak-Gould, 2018b; Kempf \& Hermann, 2014; Hofmann, 2014; Mondragón, 2014), as well as their perception and reception of social and political changes related to climatic change (Rudiak-Gould, 2011, 2013). Such research shows how climate change-related discourses are shaped by the perceptions and cultural concepts of people on the ground (Kempf \& Hermann, 2014; Hermann \& Kempf, this volume; Rudiak-Gould, 2013). This means that discourses and observations are framed by how people live in the world and can simultaneously have effects on their living (Hetzel \& Pascht, 2017). As Klepp and Chavez-Rodrigez (2018) argue, it is important to uncover how practices of political programs connected to climate change could have influences on communities. In their view social scientists must mindfully consider political processes connected to policies and measures that aim to support and enable climate change adaptation. They show the political, social, and cultural influence of climate change policies and projects on community life. We aim to think even further and look at what people who have had experience with so-called adaptation programmes actually $d o$. In Vanuatu, many programs target food security and agriculture. Focusing on people's practices during the 
project's lifetime and how they experience new knowledge and activities might give new impulses for discussions on climate change adaptation measures in Oceania.

\subsection{Perspectives on climate change in Vanuatu}

A significant amount of climate change research in Vanuatu focuses mainly on adaptation to climate change and/or on the study of the effects of so-called community-based adaptation projects and the work being done in communities (McCarter \& Gavin, 2014; Warrick, 2009, 2011). These research projects conclude that adaptation projects which are based on cooperation with the local population and incorporating so-called local knowledge are more successful. For example, Warrick (2011) answers her research question about the extent to which the established international discourse on 'adaptation' enables effective adaptation at the level of local communities by juxtaposing (science-based) approaches to adaptation with local concepts of vulnerability. Other studies focus on the practical level and the presentation of declarative and procedural knowledge (Richmond \& Sovacool, 2012, pp. 843-845; McNamara \& Prasad, 2013, 2014; Warrick, 2009, 2011). In addition to this, local knowledge on how to deal with risks is a major topic (McNamara \& Prasad, 2014; McCarter \& Gavin, 2013).

Mondragón's work concludes that the inhabitants of the Torres Islands in Vanuatu have a wealth of knowledge and practices that allow them to live with changing climatic conditions (Mondragón, 2018, p. 20). The author presents some important findings about human-environment relations of Torres Islanders: environmental changes that they considered as a confluence of spiritual forces, human agency, and other influences in the past, were seen as the result of global warming, which is perceived as a result of air pollution from foreign countries, after the arrival of science-based knowledge about climate change. He shows that local interpretive patterns can change when local actors appropriate external knowledge (Mondragón, 2018). Nevertheless, he also refers to practices of Torres Islanders engaging with their environment in a relational way between humans, spirits, and plants. In order to understand what adaptation could mean for the people of Torres Islands, Mondragón suggests that we look at the "human engagement" with the environment (Mondragón, 2018, p. 25).

\subsection{Diversifying practices}

Other research addresses the principle of diversification concerning livelihood strategies in the Pacific Islands. One example is the study by Reenberg and colleagues for Bellona on the Solomon Islands. They describe diversification of livelihood strategies as an adaptive strategy to climatic change. The authors argue that during the last decades, livelihood strategies' components have become more diverse, so that people were able to alter their activities and become less vulnerable 
to external shocks (Reenberg et al., 2008, p. 11). In their interpretation, changes in livelihood strategies "can be seen as conscious adaptive processes" (p. 7).

Diversification has also been identified as important in other (related) contexts in Oceania. In her work on Pacific foodscapes Pollock describes the history of food security in the Pacific Islands as a history of diversification. She identifies three "tides of innovation" - the early settlers, mid-18 ${ }^{\text {th }}$ to mid-20th century, and the last 60 years - when people expanded the range of cultivated food crops (Pollock, 2017, p. 265). She stresses the importance of and their interest in innovating and introducing new food plants and varieties which visitors brought to the islands. She states that diversity contributes to food security as sustainable community support because it is a "moral imperative" (Pollock, 2017, p. 267). This means that diversification here is not only a technical strategy but is also connected with people's social values.

\section{$3 \quad$ Research approach}

The results presented in this chapter are based on a team-based research design consisting in 15 months of anthropological fieldwork between 2016 and 2019 in the villages of Siviri on Efate and Dixon Reef on Malekula. During this time, we each divided our work between the two villages, so that one of us was in either village for most of the duration. Since domains for women and men are often separated in Vanuatu, this team-based approach was essential to allow us to interact with men and women in both villages. Our research methods included formal and informal interviews in combination with participant observation and structured observation, touching social, economic, and political aspects of community life. Additionally, we conducted 92 household surveys and used other methods such as drawing moving maps to learn about practices in and on the way to the gardens and going on guided walks, which allowed us to explore especially important places inside and outside the village and the gardens (see O’Neill \& Hubbard, 2010; Pink, 2008). Since we stayed more than one year, we experienced the praxis of a full circle of gardening and other activities inside the communities. When we arrived at the end of 2016, the topic of El Niño which caused an extended dry period in 2015 was very present in the discourses and praxis of the people.

Siviri and Dixon Reef were mainly chosen as research sites because adaptation to climate change projects (in combination with food security) had been implemented in both communities for some years. We positioned ourselves as independent researchers from a German University vis-à-vis the community and the organisations running the adaptation workshops and trainings. 


\section{The ethnographic setting}

Vanuatu, an island state in the South Pacific, is geographically part of Oceania. It is one of the states, together with Fiji, New Caledonia, Solomon Islands, and Papua New Guinea, grouped in the sub-region of Melanesia. The 83 islands of the Yshaped archipelago stretch over an area of 12,190 km² (Mückler, 2010, p. 162). Our research sites were located on two of the bigger islands, Malekula and Efate (see Figure 1), which are volcanic islands with upraised tertiary limestone (Brookefield \& Hart, 1971).

In general, the bigger islands of Melanesia are characterised by higher rainfall than low-lying atoll islands in other regions of Oceania. But there is a great variation of precipitation among places on the islands (see Bell et al., 2001). In the case of the two communities of Siviri and Dixon Reef, adaptation programmes were designed to face longer dry periods between May and October.

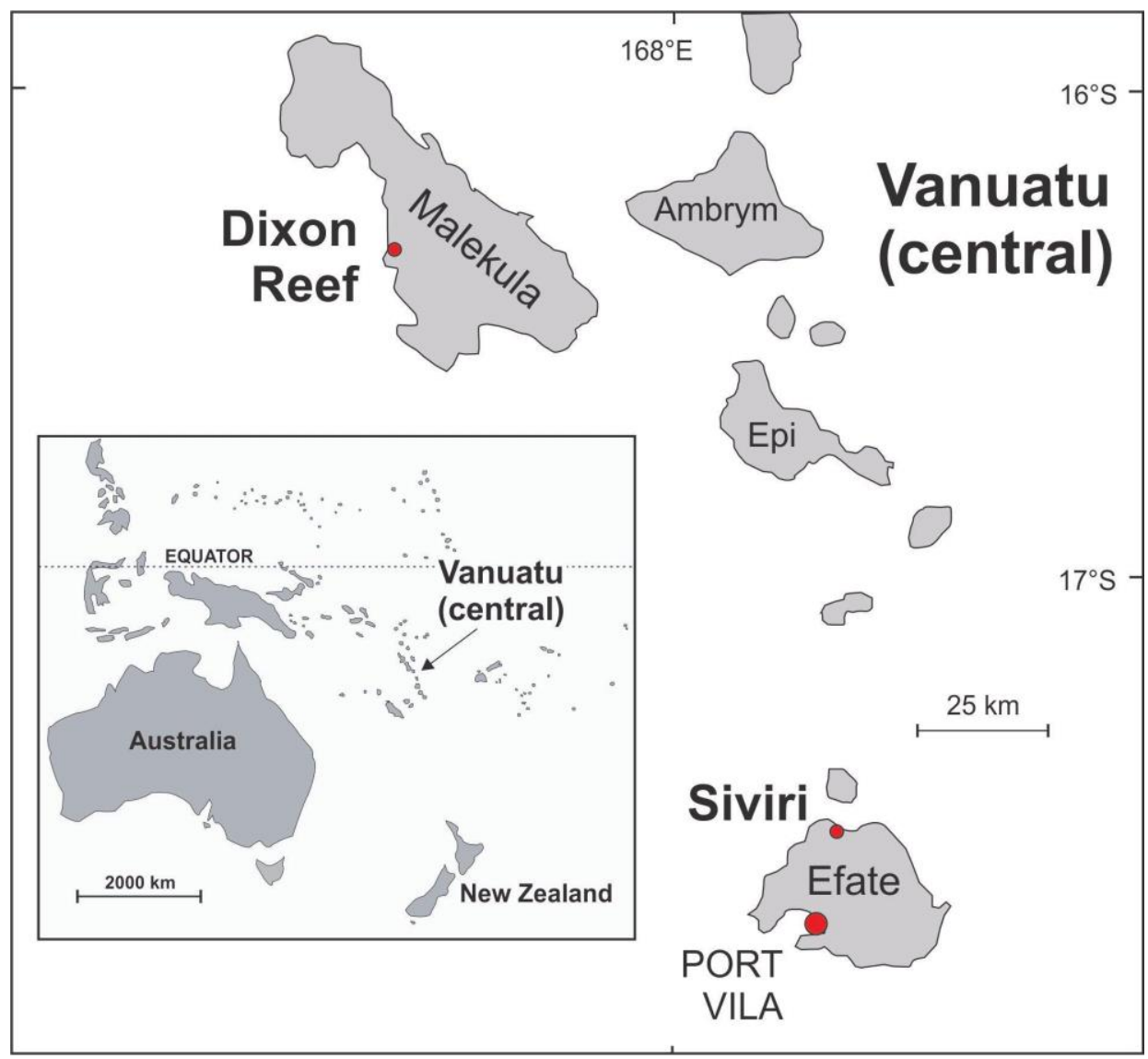

Figure 1: Location of Vanuatu in the Pacific, and of the two research sites in Vanuatu. Map: Patrick D. Nunn 
Agriculture forms the economic basis of Vanuatu. Of the country's population of approximately 270,000 (VNSO, 2016, p. 1), more than $80 \%$ live in rural areas and practise horticulture (Fallon, 1994, p. 37). Vanuatu is characterised by subsistence farming, supplemented with some cash crops, which are mainly sold at local markets or, in the case of North Efate, at the main market in the capital Port Vila (FAO, 2008, pp. 34-40). Members of the two communities we worked with predominantly practise horticulture (with some arboriculture) in the form of shifting cultivation, mostly for subsistence, but sometimes they engaged in cultivation to produce surplus for sale (see Manner \& Thaman, 2013). In both villages we worked in, community members described their life as a village-based life, although, as we will discuss below, in both communities livelihood practices included more aspects than horticulture.

The village communities of Dixon Reef on Malekula and Siviri on Efate consist of approximately 200 to 250 inhabitants comprising 39 to 44 households each. People live in nuclear or extended families of up to three generations. These relatively small groups may (temporarily) be joined by other relatives or workers. Even though they might have different houses for sleeping, all household members share one kitchen house and cultivate family gardens. Commonly, sleeping, cooking, and 'storian' 3 are carried out in a yard containing several separate houses or shelters. Villagers spend many hours of every day outside, circulating between different households, working places, and the gardens. Garden plots can be located either close to the dwelling houses or hours of walking distance away from the village. They can cover an area of between $20 \mathrm{~m}^{2}$ and $1 \mathrm{ha}\left(10,000 \mathrm{~m}^{2}\right)$.

\subsection{Siviri}

The village of Siviri is located in North Efate, some $40 \mathrm{~km}$ from Port Vila. People have easy access to the town since the village is located close to the main road which circles the island. Transport of goods and people to the capital and to some of the more distant gardens is possible. During weekdays, humans, garden crops, and other foods travel in and out of the village. In many families at least one person works in town, mostly in the education sector, the service sector, or construction. 'Mekem karen', cultivating in Bislama ${ }^{4}$, is carried out at any time, but is especially scheduled for the weekends, when school children are at home and can join their parents. Especially during the planting season for yams (Dioscorea), which starts in the beginning of August, parents, grandparents, and children gather together and spend the whole day in the family gardens. For some years now, people have moved their gardens closer to their houses or at least installed one additional

\footnotetext{
${ }^{3}$ Storian in Bislama means conversation and also the leisure time that is spent among families and friends.

${ }^{4}$ Bislama, a pidgin language was declared the national language shortly before Vanuatu gained independence in 1980 (see Gundert-Hock 1984, p. 202)
} 
garden next to their kitchens. During the time of our stay in 2017, many families and women grew island cabbage (Abelmoschus manihot) and other vegetables next to their houses. Although every family had a garden, they all bought a considerable part of their food supply from markets or shops in Port Vila and small road markets. The cash economy and wage labour have become increasingly important over the past decade and many people stated that they have less time for gardening than they did a few years ago. Nevertheless, every family member had access to crops coming out of their gardens. One elderly man described it as follows: "If you have a job in town it's good, but still you have to have your garden, so that you do not depend on the food in the stores".

\subsection{Dixon Reef}

Dixon Reef (or Tavendrua) is located on the southwest coast of the island of Malekula, the second largest island of Vanuatu which is part of the Malampa Province in the northern part of the country. At the time of our research, the village of Dixon Reef was reachable by small boats three times a week, and people only travelled for bigger shopping trips, ceremonies, or other visits. Malekula is a volcanic island and is densely forested with fertile soil inland (Barrau, 1958, p. 35). Missionaries were successful in resettling people closer to the sea. This also had consequences for cultivation - people had to deal with less fertile soil for horticulture and they were confronted with extended dry weather periods. Today villagers in Dixon Reef do not plant on the sandy soil along the village border and accept walking distances of about one hour following the route inland or uphill to reach their garden plots.

Village life is organised according to the seasons of yam cultivation and the tuber is used for both consumption and ceremonial purposes. Everyone in Dixon Reef practices horticulture from an early age, and families can have as many as 18 gardens. The main food resources originate from these gardens, while hunting wild pigs, practising onshore fishing, and/or keeping cattle and chickens help supplement the diet. In 2017, villagers additionally bought rice (especially after Tropical Cyclone Pam), but in 2019 the consumption of rice had already declined. In Dixon Reef, villagers also have cash income. As in many other places in Vanuatu, cash is derived mainly from selling copra, timber, cocoa, and kava (Rousseau \& Taylor, 2012, p. 174; McCarter \& Gavin, 2014). Once a month ships pass to transport or buy the dried fruits, and this has become an important source of income over the last years. 


\section{Climate change in Vanuatu}

In an international context, Vanuatu is classified as a Small Island Developing State (SIDS) and accordingly regarded as highly vulnerable to climate change (Kelman \& West, 2009, p. 3; Connell, 2013). Reports and prognoses show multiple challenges for Vanuatu: the country is extremely vulnerable to natural hazards such as hurricanes, floods, earthquakes, landslides, tsunamis, and so on (FAO, 2008, p. 32). It is likely that climate change and the related higher number of extreme weather events will mean additional stress for agriculture (ibid., p. 39). This would mean that people in rural areas in particular have to deal with problems cultivating their crops because of augmented temperatures, more frequent dry periods, and higher variability of rainfall, intrusion of salt water, erosion, hurricanes, and other phenomena in connection with climate change. It is expected that these effects will have negative impacts on agriculture, and that water management will become more difficult and more crucial (ibid., p. 50). Water shortage and the loss of planting material are two of the key problems mentioned in studies among farmers across Oceania (McNamara \& Prasad, 2014).

For many years climate change has been one of the major topics in political discourse in Vanuatu. As one of the first states in Oceania to develop such a programme, Vanuatu submitted its National Adaptation Programme of Action (NAPA) in 2007 (NACCC, 2007). This document has identified agriculture and food security, as well as sustainable tourism development, community-based marine resource management, and sustainable forestry management as priorities (Bijay, Filho, \& Schulte, 2013; NACCC, 2007). In particular, small-scale farming is one of the important topics when addressing climate change adaptation. Corresponding to the proposed climate change impacts listed above, the state has adopted a range of measures. Climate change policies and laws have been introduced, policies and legal regulation for various topics have undergone climate mainstreaming, and a ministry of climate change as well as a National Advisory Board on Climate Change and Disaster Risk Reduction have been established. Most importantly, a great number of projects for climate change adaptation have been, and are being, carried out targeting challenges in agriculture. Government and other organisations have designed measures for food security and climate change adaptation during the past few years - mostly for rural communities. These projects have been realised and financed almost exclusively by foreign organisations. In a great number of cases these organisations cooperate with Vanuatu state institutions like the agriculture or forestry ministry. Measures are implemented both by ni-Vanuatu and by international staff. A number of these measures aim to improve and support family farming for subsistence and the market. Staff of the agriculture department and of an NGO we talked with were convinced that techniques taught in the so-called climate change and food security workshops could prepare farmers for challenging times, like those expected in the future, giving them expertise to restore ground fertility and work their garden plots with different kinds of planting techniques 
adapted to the dry weather conditions. The government and non-governmental programs have made climate change and successive consequences for the rural population one of the priorities over the past years.

After Tropical Cyclone Pam, members of the Vanuatu government as well as of non-governmental organisations declared the storm to be one of the predicted extreme weather events and a clear sign of progressing environmental damage caused by climate change. A younger employee at one of the NGOs pointed out: "This is a clear sign and this is what we have been preparing for over all these years".

During the weeks after the cyclone, official statements of politicians were distributed countrywide via the local newspaper and the radio. For many of our interlocutors in Siviri, especially those in their twenties, it was the strongest storm they had ever experienced. There was far less damage on Malekula since Pam passed in the east of Vanuatu and moved south afterwards (Calandra, 2019). Most of our interlocutors in both locations explained that the main problems they faced began in the aftermath of Pam by the time of November 2015 when the rainy season brought no precipitation. They called this dry time El Niño and according to the villagers it lasted until the beginning of 2017. They considered this an even bigger challenge than the storm itself.

\section{Dealing with climate change through new measures}

In the two villages of Siviri and Dixon Reef, measures designed to improve food security in combination with climate change adaptation and sometimes mitigation were implemented. NGO representatives held workshops ${ }^{5}$ over a period of at least four years between 2012 and 2019. Over the runtime, our interlocutors told us that they attended workshops every two or three months, which provided scientific background knowledge in combination with practical exercises for implementation.

In both communities, people tried out newly learned techniques on village demonstration plots. One important goal was to change ways of cultivating food crops so that food security is ensured despite adverse impacts of climate change (and other constraints). This means that people should use those techniques and methods in order to secure the supply of food through their own gardens and preferably at the same time to produce surplus that they are able to sell. The objective was that small-scale farmers would "have access to knowledge on improved integrated, intensive, organic gardening methods" (NAB, 2018).

In the following paragraphs, we give an overview of the approaches and agricultural techniques that were part of the food security programme.

\footnotetext{
${ }^{5}$ There was a variety in gender and age of the participants in both communities and every community member attended at least one workshop.
} 
Moving vegetable gardens closer to the houses was intended to make nutritious food easily accessible, even during dry periods typically experienced in both villages every year, which can have an immense effect on agriculture. In Dixon Reef the installation of house gardens, mainly with island cabbage and legumes, was supposed to provide daily vitamin-rich nutrition. For these gardens, particular principles of permaculture were communicated in workshops and training sessions. Examples are the use of greywater for irrigation, the production and use of compost, and mulching. These principles and techniques were also practically introduced in the community of Siviri, and workshop leaders explained, for example, the use and benefits of liquid organic fertilisers.

Planting material multiplication with yam-minisett was demonstrated in both villages. This method is intended to multiply planting material for situations after an environmental hazard like a cyclone, drought, or flooding when many plants used for vegetative propagation are destroyed.

One of the few methods actually used by a number of farmers was also shown in both Siviri and Dixon: organic fertilising with nitrogen-feeding trees such as Gliricidia (gliricidia sepium), which are planted in rows inside or around garden areas. This is intended to prevent people from regularly burning down trees in order to clear new plots of planting land. Planting nitrogen-feeding plants should enable them to instead plant gardens repeatedly in the same spot - a goal all staff members of NGOs we talked with vehemently pursued. Staff from NGOs as well as from the agriculture department of Vanuatu decidedly discouraged the method of burning to prepare gardens for planting. One staff member of the NGO working in Dixon Reef explained that she encourages people not to destroy the forest further by burning, because this "disturbs the normal course of the weather pattern". The staff member of the agriculture department working with people in Siviri stressed that burning "destroys the environment, because it makes the ground dry". Because one possible impact of climate change is a higher frequency of dry periods, activities which result in drying out the soil should be avoided. Instead, project representatives highly valued caring for garden plots and using new agriculture techniques for sustainable gardening, including mulching to prevent drying and to fertilise the ground.

Additionally, staff of NGOs and the agriculture department explained to people in the villages that the Gliricidia trees used for fertilising additionally provide shade so that the soil will not dry off in times of drought and that they act as a windbreak during tropical storms and cyclones. In Dixon Reef they also presented some other minor techniques like using sticks instead of trees for the vines of yams to grow on. In Siviri an NGO demonstrated how to plant crops in a plastic bag which can be stored in a safe place during a cyclone. In Dixon Reef most of the new techniques were shown in a demonstration plot which was for the use of the whole village.

In both villages people were interested in the projects and participated in the workshops. According to our interlocutors in both places, they highly appreciated 
new methods and techniques for subsistence (or commercial) agriculture presented by staff of NGOs and government institutions. In their view, the knowledge gained might become relevant in the future if weather or other conditions change. In Dixon Reef, women and men subsequently installed a number of house gardens, using techniques demonstrated during the workshops. In Siviri, Gliricidia was planted and one of our interlocutors told us that he used the yam planting multiplication material. People thus were seen by staff of NGOs and government as well prepared to supply themselves with food from their gardens during times of environmental challenges such as cyclones or droughts. In the long run, however, the people responsible for the programmes were surprised that, after showing enthusiasm in the first place, many participants did not implement most of the new methods and techniques. Since they were eager to teach people in rural areas to help them to be secure and prepared for future events some found it frustrating to see that there was no continuity in the practices of participants. However, as we learned from a number of people we spoke with, they indeed did not abandon the newly learned techniques, but rather combined livelihood practices synchronously and diachronically.

\section{$7 \quad$ People's livelihood practices: combining and expanding networks}

Statements and practices of men and women in Siviri and Dixon Reef revealed that they did not concentrate on gardening alone, but combined established livelihood practices, innovative possibilities derived from diverse sources, and practices of maintaining food security presented during workshops and training sessions. Additionally, they not only drew on suggestions made during these events, but also chose various (other) ways of making their living. As one middle-aged man in Siviri explained: "You have to do different things. You cannot just do one thing or stay at home. Man Vanuatu has to move".

In the following paragraphs we explain people's livelihood practices and the continuous diversification of these practices, and show the different characteristics of cultivation and wage labour.

\subsection{Siviri: combining practices}

In Siviri, Tropical Cyclone Pam caused severe damage to houses and gardens. Although people were able to rebuild their houses quickly, we were told that the cyclone destroyed recently planted yam and vegetable gardens. Immediately after the storm, the inhabitants of Siviri received food supplies for a few months, which the government and aid organisations disseminated. The Vanuatu Agriculture Department provided planting material to replace lost fruits and root crops (such as cassava (manihot esculenta), white cabbage, tomato, lettuce, and pumpkin) so that 
villagers would be able to replant food plants. Additionally, people in Siviri immediately contacted family members living on other islands across Vanuatu, which had been less affected by the storm, requesting crops or seedlings. Asking family members for planting material and buying crops to plant them in one's own garden is a strategy we could observe during the whole time of our research.

Some difficulties only became clear months after the cyclone. Many of our interlocutors explained that although they had planted considerable amounts of food plants during the months after the cyclone, the yield was significantly lower than the years before. They referred not only to a reduction of subsistence crops but also to a decline of food production for the market. Before the cyclone took place, growing crops for the market in Port Vila was one of the main sources of income for many of the households in Siviri, whereas during our stay only a few women went regularly to the market in the capital to sell their agricultural produce.

In order to pursue their living, our interlocutors told us that in many households members combined several livelihood practices, most simultaneously. With a few exceptions they continued planting food crops. They resumed cultivating their gardens as soon as possible - though many in considerably smaller capacity than during the time before the cyclone, and in a number of cases in different places, using different techniques. Irrigation was one strategy that was used when rainfall was exceptionally low.

Several people who continued commercial or subsistence planting used some of the techniques that were communicated during adaptation workshops. This included mostly the planting of Gliricidia and other organic fertilisers. Nearly everyone used the new cassava planting technique and a few the new method of multiplying planting material for yams. Many of the villagers who did not use the new techniques explained them in detail to us and assured us that they could use them at any time.

During our work in Siviri, we observed villagers gardening next to their houses, and conversations revealed that people had reduced the number of gardens in areas more distant from their houses. Some even shifted their planting activities completely to their home gardens.

In addition to gardening, even more villagers found employment in the capital Port Vila or elsewhere on the island of Efate. There is a great variety of different kinds of wage labour being practised. Our interlocutors explained furthermore that a new development in Siviri was the increase of cutting firewood and selling it at the market in Port Vila, and they also mentioned an increase in cutting and selling fence posts and timber. Mostly people used these options as a supplement to others.

One couple explained how they manage to combine different activities by sharing the work and distributing the work throughout the day. The man did his job in the city on weekdays. The woman, because her husband was often absent, moved one of the gardens next to their home so that she could do the work alone. In their spare time, for example on Saturdays, they planted food crops in gardens 
that are more distant. In the evenings they ran a kava bar where they also sold some prepared food.

Some of the inhabitants of Siviri continued to make use of several other possibilities - for example the commercial breeding of pigs and fowl or fishing. Good opportunities exist to sell pigs or fish to hotels or in the markets in Port Vila and elsewhere, or informally locally. Recently a number of women in the village began to engage in producing pieces of handicraft to sell at the recently built handicraft market in Port Vila. A future-oriented option is the planting of precious wood such as mahogany or sandalwood for the benefit of their children rather than for income for themselves, but others hope to make a profit during their lifetime.

\subsection{Dixon Reef: garden networks}

Tropical Cyclone Pam did not affect Dixon Reef directly, but our interlocutors complained about their problems cultivating yam and banana plants during the following dry period. They told us that the yield in many gardens was lower due to little rain.

After the cyclone, villagers were focused on their gardening practices, but tried to make sure that multiple options of livelihood practices were available. In fact, cultivation was important for creating (new) options of livelihood practices for people in Dixon Reef. While earlier gardening practices were kept, some new ones were added and integrated into the existing network, and some were temporarily introduced.

One longstanding practice of gardening in Dixon Reef is that gardens are located in different locations, which provide appropriate conditions throughout the seasons. Daily routines consist in walking within the wider environment, visiting several gardens in a day, harvesting in one, carrying planting material to the next, and returning to the house with bundles of coconuts collected from the plantation along the road leading to the village. Over time, many families have extended this network of gardening and established additional new gardens in areas where they found humid soil, for example along the river, directly in the dry river bed, or in a swamp. During wet periods they move their gardening further up the steep hills or shift to the ground further inland or closer to neighbouring villages. Our interlocutors identified seasonal planting in different places as a long-established method to ensure sufficient supply of staple crops such as yam, cassava, and island cabbage.

Villagers additionally follow routine experimental practices, which includes trying out new methods. In line with this agricultural approach of trial and error, people were eager to involve new techniques learned during the workshops into their existing practices. For example, a number tried nitrogen fertilising with Gliricidia and protecting the ground by mulching. The small house gardens, a food security strategy intensely promoted by one of the NGOs, were managed in different phases. Whereas directly after workshops one could find these gardens in a high number of households, in the further course, and in 2017 as well, we could 
only record a small number of house gardens. In interviews, various reasons for this were mentioned: some of our interlocutors explained that the chickens, which are mostly not fenced in Dixon Reef, destroyed the harvest. They argued that it would be a lot of work or money to install a proper fence so that chickens are not able to enter the gardens. Others mentioned that the water supply in the village is not constant so that it is not possible to irrigate the gardens sufficiently. One woman continued a house garden and a few new ones were installed during our stay. One woman put it this way: "I tried to do it and it worked - maybe I try it again".

In addition to gardening, we observed that some people supplemented their livelihoods through other activities, mainly catching and selling fish. During our stay, three people also began to build a chicken pen in order to be able to sell chicken and eggs.

People explained that buying rice and other food is an important supplement for their daily diet. In order to obtain the necessary money, people spent a considerable amount of time in the plantations in order to harvest coconuts, remove the flesh from the shell, and dry it in order to obtain copra, which is then sold to regularly visiting copra buyers. Another important activity in order to earn cash is the production of cocoa, which is even more labour-intensive. With very few exceptions, inhabitants of Dixon Reef did not plant kava themselves, but imported it mainly from the Southwest Bay region of Malekula. However, during the time we spent in the village, a group of people set out for a place further inland where they stayed for some days and planted large amounts of kava. This is, we were told, because the price of kava had risen considerably during the previous couple of years.

\section{Conclusion}

In this chapter we explored livelihood practices of people in Siviri and Dixon Reef during and after Tropical Cyclone Pam, the drought, and the food security and climate change adaptation workshops. This revealed that the villagers performed a great variety of activities in order to secure their food supply from their gardens and their monetary income.

In Siviri, cultivation was still practiced in order to obtain food directly or to sell it, but in lower quantity than before the cyclone. Here some of the newly learned practices were used sporadically. Additionally, the villagers engaged in a wide variety of different kinds of wage labour. Furthermore, self-employment, such as selling firewood, fenceposts, timber, or charcoal were important practices for many to earn money. Most households combined cultivation with one or two other kinds of livelihood practices so that they were able to buy food and other necessities in stores and at markets. This means that residents found or created and realised various ways of maintaining their livelihoods. 
During and after the drought, the most important livelihood practices in Dixon Reef were related to cultivation of food crops. Characteristically, people planted a range of different crops and a relatively high number of crop varieties in various places. People continued to use already known gardening practices, but they also (at least temporarily) made use of a few new techniques. They also employed a variety of other options to pursue their livelihoods, turning to possibilities which enabled them to buy food - especially to the production of copra. This means that instead of concentrating on just a few practices, people established new ways of extending possibilities of ensuring a good life for their families and continuously circulated these in the community.

Working out ways of making a living, people engaged with and in their respective environments (Hetzel \& Pascht, 2017), including not only infrastructure, places, and people, but also ideas and knowledge. Our interlocutors created specific kinds of diversification when they engaged with local environments and conditions. Every household followed more than one possibility. In both places, the result was a combination of diverse possibilities. People in Siviri combined cultivation of their gardens, which they partly shifted closer to their houses, with a great variety of options to earn money, so that they were able to buy food and other necessities at markets and stores. People in Dixon Reef continued to concentrate on cultivating a range of different varieties of food crops. They planted their gardens in different places, some in places especially appropriate for dry weather conditions. But they also engaged in some possibilities for monetary income in order to buy food, especially rice. Thus in both places people did not concentrate on one livelihood option, but engaged in a broad variety of possibilities.

As we stated above, our interlocutors in Siviri and Dixon Reef, irrespective of their age and social position, were eager to find out about innovative techniques and methods for gardening or horticulture. At the same time, they were similarly interested in both old and new ideas about other options to pursue their livelihoods. Additionally, they were very open to replacing practices, adding new ones, or resuming practices that seemed to have been abandoned when they thought them to be appropriate. They told us that they quite often switched to alternative possibilities in the past. This resulted in a very changeable sequence of more than one livelihood practice being used at the same time, without recognisable permanence of practices, and without linearity in implementing knowledge into practice. People actively decided for or against particular options out of the many possibilities they engaged in according to the specific conditions of the current context.

Now, is this specific process of diversification related to the drought after the cyclone or to people's encounter with new ideas about cultivation through workshops on climate change? The initial interest of villagers in new cultivation techniques and methods presented during workshops and training sessions of the food security and adaptation projects did not lead to a continuity of following new practices; only a few participants put them into practice for longer periods or at all. Yet, regardless of this, people we talked with were still interested and knowledgeable 
about them. During the drought, while people continued planting gardens for food supply, they slightly shifted the focus of their livelihood practices to other options like selling firewood or copra, but at the same time maintained other activities and thus broadened the diversity of their livelihood practices.

Looking at the main Melanesian livelihood practice, namely horticulture, the practice of diversification can be found in numerous places in the region. People in these places do not specialise in the cultivation of one main staple crop but plant a great variety of crops. Barrau (1958, pp. 61-63) shows that during his research in the 1950s in various places in Melanesia people did not rely on one staple, but planted five or more species. We observed this phenomenon in Vanuatu during our recent fieldwork where people mostly plant at least yam, taro, banana, manioc, and sweet potato as staple foods. An even greater diversification can be observed regarding the varieties of one species of food plant. William Clarke stresses that planting a high number of named varieties within many species is of great significance in the Pacific Islands. He reports the example of Pohnpei in Micronesia, where 150 varieties of breadfruit existed (Clarke, 1994, p. 21). As stated above, Pollock shows that during the history of Pacific Islanders a continuous process of diversification of the cultivation of food crops took place and she stresses that this is linked to social values.

Our interlocutors told us that their ancestors planted numerous varieties of their cultivated species. Although they stressed that they are planting fewer varieties of yam and other food plants today, we observed that people are still cultivating a relatively great diversity of varieties. This suggests that creating diversity in the realm of cultivation is an established practice in Vanuatu.

In our interpretation, people of Siviri and Dixon Reef transfer this practice of creating diversity from cultivation to other realms of livelihood practices. As in Pollock's interpretation, diversification here contributes to food security, albeit with various options outside the realm of cultivation as well (Pollock, 2017). In the process of active engagement with their environments, villagers constantly aspire to expand their options for livelihood security, also, but not exclusively, in times of environmental challenges. At the same time, they extend their knowledge of (new) people, things, places, and practices, creating and re-creating networks of known humans, other-than-humans, and activities. Livelihood practices in Siviri and Dixon Reef did not become significantly more diverse and do not provide a significantly wider range of options after the adaptation projects. People in both villages continued with their praxis of engaging in multiple activities of different kinds and multiple places with multiple materials. Rather than specialising in one kind of activity, one place, one kind and variety of plants, they specialised in diversifying. Whereas people in Siviri were engaging in a variety of wage labour options - besides other activities like cultivation - people in Dixon Reef were engaging in various places - but also in other possibilities like copra and cocoa cultivation. This means that by referring to established and new practices they constantly generated (new) diversified practices. 
Looking at the practices and the agency of people, as we show in this chapter, opens the perspective to a wide range of aspects superficially not connected to 'adaptation to climate change'. People did refer to the drought after Tropical Cyclone Pam and to the new (practical) knowledge they came to know in workshops and demonstrations. They employed it for their practice of diversifying which they apply, among others, in the realm we call livelihood practices.

It may be apt to explain this process as a creation of a knowledge space which is "made up of linked sites, people and activities" (Turnbull, 2003, p. 19) and where people are open to integrating and assembling knowledge from different sources (Hastrup, 2015, p. 150; Hetzel \& Pascht, 2018).

By interpreting diversification and changes in livelihood strategies as established practices in the two villages we aim to expand the view from adaptation as an isolated process to a more holistic approach where environment is not confined to the physical sphere but where there is no separation between the social, the physical, and the other-than-human spheres. Looking at the active engagement and interaction of people with the material and non-material conditions they encounter in their daily life praxis enables in our opinion a meaningful dialogue with them. 'Climate change' in this dialogue is not yet defined, but a concept which is generated by researchers and interlocutors in the encounters.

\section{Bibliography}

Barrau, J. (1958). Subsistence agriculture in Melanesia. Bernice P. Bishop Museum Bulletin No. 219.

Bell, J. D. et al. (2011). Vulnerability of tropical Pacific fisheries and aquaculture to climate change: Summary for Pacific Island countries and territories. Secretariat of the Pacific Community, Noumea, New Caledonia.

Bijay, P., Filho, W. L., \& Schulte, V. (2013). Understanding the links between climate change and disaster management in Pacific Island countries. In W. L. Filho (ed), Climate change and disaster risk management. Berlin (pp. 55-70). Heidelberg: Springer.

Brookfield, H. C., \& Hart, D. (1971). Melanesia: A geographical interpretation of an island world. Methuen's advanced geographies. London: Methuen.

Calandra, M. (2019). Disasta: Rethinking the notion of disaster in the wake of Cyclone Pam. Anthropological Forum.

Clarke, W. C. (1994). Traditional land use and agriculture in the Pacific Islands. In J. Morrison, G. Paul, \& L. Crowl (Eds.), Science of Pacific Island peoples: Vol. 2. Land use and agriculture (pp. 11-38). Suva, Fiji: Institute of Pacific Studies.

Crook, T., \& Rudiak-Gould, P. (2018a). Introduction: Pacific climate cultures. In T. Crook \& P. Rudiak-Gould (Eds.), Pacific climate cultures: Living climate change in Oceania (pp. 1-20). Warsaw: De Gruyter. 
Crook, T., \& Rudiak-Gould, P. (Eds.). (2018b). Pacific climate cultures: Living climate change in Oceania. Warsaw: De Gruyter.

Dürr, E., \& Pascht, A. (Eds.). (2017). Environmental transformations and cultural responses: Ontologies, discourses, and practices in Oceania. New York: Palgrave Macmillan.

Fallon, J. (1994). The V anuatu economy: Creating conditions for sustained and broad based development. International development issues: no. 32. Canberra: Australian International Development Assistance Bureau.

FAO. (2008). Climate change and food security in Pacific Island countries. Rome: Food and Agricultural Organisation of the United Nations (FAO).

Farbotko, C. (2010). "Wishful sinking. Disappearing islands, climate refugees and cosmopolitan experimentation." Asia Pacific Viewpoint, 51(1), 47-60.

Government of Vanuatu (GoV). (2015). Tropical Cyclone Pam - Humanitarian Action Plan. Retreived from https://reliefweb.int/sites/reliefweb.int/files/resour ces/vanuatu_tc_pam_hap.pdf.

Granderson, A. A. (2014). Making sense of climate change risks and responses at the community level: A cultural-political lens. Climate Risk Management, 3, 55-64.

Gundert-Hock, S. (1984). Der Historische Rabmen der Wirtschaftlichen und Politischen Entwicklung von Vanuatu. München: Minerva.

Hastrup, K. (2015). Comparing climate worlds: Theorising across ethnographic fields. In H. Greschke \& J. Tischler (Eds.), Grounding global climate change (pp. 139-154). Dordrecht: Springer Netherlands.

Hetzel, D., \& Pascht, A. (2018). Young ni-Vanuatu encounter climate change: Reception of knowledge and new discourses. In E. Dürr \& A. Pascht (Eds.), Environmental transformations and cultural responses: Ontologies, discourses and practices in Oceania (pp. 103-124). New York: Palgrave Macmillan.

Hofmann, R. (2014). Culturecide in changing Micronesian climates? About the unintenionality of climate change. International Journal of Human Rights, 18(3), 336-349.

Hviding, E. (2003). Both sides of the beach: Knowledges of nature in Oceania. In H. Selin (Ed.), Nature across cultures. Views of nature and the environment in nonWestern cultures (pp. 245-288). Dordrecht: Springer Netherlands.

Ingold, T. (2002). The perception of the environment. London: Routledge.

Kelman, I., \& West, J. J. (2009). Climate change and Small Island Developing States: A critical review. Ecological and Environmental Anthropology, 5(1), 1-16.

Kempf, W., \& Hermann, E. (2014). Uncertain futures of belonging: Consequences of climate change and sea-level rise in Oceania. In E. Hermann, W. Kempf, \& T. van Meijl (Eds.), Pacific perspectives: Volume 3. Belonging in Oceania: Movement, place-making and multiple identifications (pp. 189-213). New York; Oxford: Berghahn.

Klepp, S., \& Chavez-Rodriguez, L. (2018). Governing climate change: The power of adaptation discourses, policies and practices. In S. Klepp \& L. ChavezRodriguez (Eds.), A critical approach to climate change adaptation: Discourses, policies, 
and practices. London; New York: Routledge Series: Routledge Advances in Climate Change Research.

Lazrus, H. (2012). Sea change: Island communities and climate change. Annual Review of Anthropology, 41(1), 285-301.

Manner, H. I., \& Thaman, R. R. (2013). Agriculture. In M. Rapaport (Ed.), Environment and society, revised edition. The Pacific Islands (pp. 341-354). Honolulu: University of Hawai'i Press.

McCarter, J., \& Gavin, M. C. (2014). In situ maintenance of traditional ecological knowledge on Malekula Island, Vanuatu. Society \& Natural Resources, 27(11), 1115-1129.

McCarter, J., \& Gavin, M. C. (2014). Local perceptions of changes in traditional ecological knowledge: A case study from Malekula Island, Vanuatu. AMBIO, 43(3), 288-296.

McNamara, E., \& Prasad, S. S. (2013). Valuing Indigenous knowledge for climate change adaptation planning in Fiji and Vanuatu. Traditional Knowledge Bulletin Tropical Issues Series, pp. 1-7.

McNamara, K. E., \& Prasad, S. S. (2014). Coping with extreme weather: Communities in Fiji and Vanuatu share their experiences and knowledge. Climatic Change, 123(2), 121-132.

Mondragón, C. (2014). Sudden environmental change. Sea level fluctuations and local perceptions of climate change in Melanesia. An assessment of a small ilsland society in North Vanuatu. In K. G. McLean (Ed.), Indigenous peoples, marginalized populations and climate change: Vulnerability, adaptation and traditional knowledge. Cambridge: Cambridge University Press.

Mondragón, C. (2018). Forest, reef and sea-level rise in North Vanuatu: Seasonal environmental practices and climate fluctuations in island Melanesia. In D. Nakashima, I. Krupnik, \& J. T. Rubis (Eds.), Indigenous knowledge for climate change assessment and adaptation, Volume 4 ( pp. 23-40). Cambridge: Cambridge University Press.

Mückler, H. (2009). Einführung in die Ethnologie Oreaniens. Kulturgeschichte Oreaniens: $B d$. 1. Vienna: Facultas.wuv.

National Advisory Board on Climate Change and Disaster Risk Reduction (NAB). (2018). Kaikai blong laef - ADR A V anuatu food security pilot project. Retrieved from http:// nab.vu/projects/kaikai-blong-laef-adra-vanuatu-food-security-pilotproject\#maptop_key_1.

National Advisory Committee on Climate Change (NACCC). (2007). National adaptation programme for action (NAPA). Port Vila: Republic of Vanuatu.

O’Neill, M., \& Hubbard, P. (2010). Walking, sensing, belonging: Ethno-mimesis as performative praxis. Visual Studies, 25, 46-58.

Pascht, A., \& Dürr, E. (2017). Introduction. In E. Dürr \& A. Pascht (Eds.), Environmental transformations and cultural responses: Ontologies, discourses and practices in Oceania (pp. 103-124). New York: Palgrave Macmillan. 
Pink, S. (2008). Mobilising visual ethnography: Making routes, making place and making images. Forum Qualitative Sozialforschung / Forum: Qualitative Social Research, 9(3).

Pollock, N. (2017). Diversification of foods and their values: Pacific foodscapes. In E. Gnecchi-Ruscone \& A. Paini (Eds.), Tides of innovation in Oceania: Value, materiality and place (pp. 261-294). Canberra: Australian National University Press.

Reenberg, A., Birch-Thomsen, T., Mertz, O., Fog, B., \& Christiansen, S. (2008). Adaptation of human coping strategies in a small island society in the SW Pacific - 50 Years of change in the coupled human-environment system on Bellona, Solomon Islands. Human Ecology, 36(6), 807-819.

Richmond, N., \& Sovacool, B. K. (2012). Bolstering resilience in the coconut kingdom: Improving adaptive capacity to climate change in Vanuatu. Energy Policy, 50, 843-848.

Rousseau, B., \& Taylor, J. P. (2012). Kastom economi and the subject of selfreliance: Differentiating development in Vanuatu. In S. Venkatesan (Ed.), Differentiating Development (pp. 169-186). Oxford: Berghahn Books.

Rudiak-Gould, P. (2011). Climate change and anthropology: The importance of reception studies. Anthropology Today, 27(2), 9-12.

Rudiak-Gould, P. (2013). Climate change and tradition in a small island state: The rising tide. Routledge studies in anthropology: Volume 13. London and New York: Routledge.

Turnbull, D. (2003). Masons, tricksters and cartographers: Comparative studies in the sociology of scientific and indigenous knowledge. London; New York: Routledge.

Vanuatu National Statistics Office (VNSO). (2009). National population and housing census. Port Vila: Ministry of Finance and Economic Management.

Warrick, O. (2009). Climate change and social change: Vulnerability and adaptation in rural Vanuatu. Proceedings of the $11^{\text {th }}$ Pacific Science Inter-Congress. http://webist em.com/psi2009/output_directory/cd1/Data/articles/000141.pdf.

Warrick, O. (2011). Local voices, local choices? Vulnerability to climate change and community-based adaptation in rural V anuatu (Doctoral dissertation, University of Waikato). 